\title{
Pollution Evaluation and Sources Identification of Heavy Metals in Surface Sediments from Upstream of Yellow River
}

\author{
Jianxiu Hao ${ }^{1}$, Jun Ren ${ }^{1,2 *}$, Ling Tao ${ }^{1,2}$, Hongbing Fang ${ }^{1}$, Suxia Gao ${ }^{1}$, Yinping Chen ${ }^{1}$ \\ ${ }^{1}$ School of Environmental and Municipal Engineering. Lanzhou Jiaotong University, Lanzhou 730070, P.R. China \\ ${ }^{2}$ Engineering Research Center for Cold and Arid Regions Water Resource Comprehensive Utilization, \\ Ministry of Education, Lanzhou, 730070, P.R. China
}

Received: 29 January 2020

Accepted: 16 July2020

\begin{abstract}
Recently, the water quality of the second longest River in China (the Yellow river) is deteriorating severely. To investigate the heavy metals contaminated degrees, potential risks and pollution sources of heavy metals in the river, we measured the concentrations of 8 heavy metals ( $\mathrm{Fe}, \mathrm{Mn}, \mathrm{Cu}, \mathrm{Ni}, \mathrm{Zn}, \mathrm{Cr}$, $\mathrm{Pb}$ and $\mathrm{Cd}$ ) from 122 surface sediment samples collected along the upstream Yellow River. According to the results of enrichment factor (EF) analysis and the geoaccumulation index $\left(\mathrm{I}_{\mathrm{geo}}\right)$ evaluation, we found $\mathrm{Cd}$ accumulated significantly for moderately contaminated level and the other heavy metals existed at uncontaminated levels. We conducted risk assessment by using calculation of the sediment quality guidelines (TEC-PEC SQGs) and potential ecological risk index (RI), and the results implied that the concentrations of $\mathrm{Ni}, \mathrm{Cr}$ and $\mathrm{Cd}$ had potential harm for aquatic organisms and the upstream Yellow River had integral no toxic. Moreover, the results of multivariate analysis (principle component analysis, hierarchical cluster analysis and correlation analysis) indicated that $\mathrm{Fe}, \mathrm{Mn}, \mathrm{Cu}, \mathrm{Zn}, \mathrm{Cr}$ and $\mathrm{Cd}$ in the river primarily originated from natural sources, while $\mathrm{Ni}$ and $\mathrm{Pb}$ mainly derived from different human activities. In addition, partial $\mathrm{Cu}$ and $\mathrm{Cd}$ come from anthropogenic sources of $\mathrm{Ni}$ discharge.
\end{abstract}

Keywords: heavy metals, pollution evaluation, surface sediment, Yellow River

\section{Introduction}

The Yellow River, the second longest river in China, plays the crucial roles in providing the drinking water for millions inhabitants and using water for industrial and agricultural activities in the arid region of north China. However, recent studies have reported that the water quality of the Yellow River is deteriorating severely because of the enormous pollutants discharged in the river through human activities and tributaries [1-2]. Currently, the Yellow River annually receives about 3.367 billion cubic meters of sewage, but only $48.6 \%$ of wastewater and tributaries satisfy quality criteria [3]. Thus, it is properly imperative to research the pollutions of the Yellow River.

Heavy metals are concerned and considered significant pollutants of aquatic systems [4] because 
of their toxic, stable or persistent characters [5-7]. Some heavy metals can store in the tissue of biota and may finally hazard human heath through food chains [8-12]. In the aquatic systems, the heavy metals can originated from both natural sources (e.g. rock weathering, soil erosion, volcanic eruption and forest fires) and human sources (e.g. metallurgical industries, mining and smelting of metals, wastewater discharge) [13-14] .

Sediments are crucial and inherent parts of aquatic systems. Various kinds of harmful and toxic pollutants were accumulated in sediments of aquatic systems [15-16]. These pollutants in the sediments can be released and possibly give rise secondary pollution of overlying water when electrical conductivity, $\mathrm{pH}$, chemical oxygen demand and oxidation reduction potential of sediments altered [17-19]. Approximately, $85 \%$ of heavy metals in the aquatic systems are deposited in the sediments [19-21]. Therefore, sediments can act as the reservoirs and indicators for heavy metals.

At present, there have been some reports on heavy metal pollution in sediment in Yellow River basin. However, these studies selected small areas or special environmental areas in the Yellow River basin, such as the middle Yellow River reaches between Hekou Town in Inner Mongolia and Zhengzhou, Henan and Baotou section [22-23], estuary [24], a heavy industry area [25-26] and the wetland [27-28]. Their samples were taken from different parts of the Yellow River basin, such as main streams or tributary streams, floodplains or alluvial areas [25]. These previous research were limited in small and specific areas. This study area covers the whole of upper Yellow River and all samples were collected in riverbed of mainstream of the upper
Yellow River. In our study, the concentrations of 8 heavy metals were measured from 122 surface sediment samples collected along the upstream Yellow River. The objectives of the study were: (1) to assess the toxicity of the sediment; (2) to investigate the spatial distribution maps of heavy metals contamination; (3) to explore dominating sources of heavy metals in sediments of the upstream Yellow River. The results may provide valuable scientific basis for the government to make reasonable policies of managing the regional water environment.

\section{Material and Methods}

\section{Study Area}

The Yellow River is the largest water resources of northwest regions of China, providing agricultural irrigation water for $15 \%$ and domestic water for $12 \%$. Approximately $40 \%$ of its runoff comes from the upstream Yellow River [29-30]. The upstream Yellow River starts from the Bayan Har Mountains of Qinghai province to Hekou Town (Togtoh County) of Inner Mongolia autonomous regions through four provinces for Qinghai, Gansu, Ningxia and Inner Mongolia and three metropolitan area for Xining, Lanzhou and Yinchuan. The length and basin area of the upstream Yellow River is $3,472 \mathrm{~km}$ and $386,000 \mathrm{~km}^{2}$, accounting for $63.5 \%$ of the total length and $51.4 \%$ of the total area respectively. In decades, the amount of domestic and industrial sewage discharged into the upstream Yellow River shows an increasing trend and water quality is deteriorating gradually [31]. In addition, for the sake

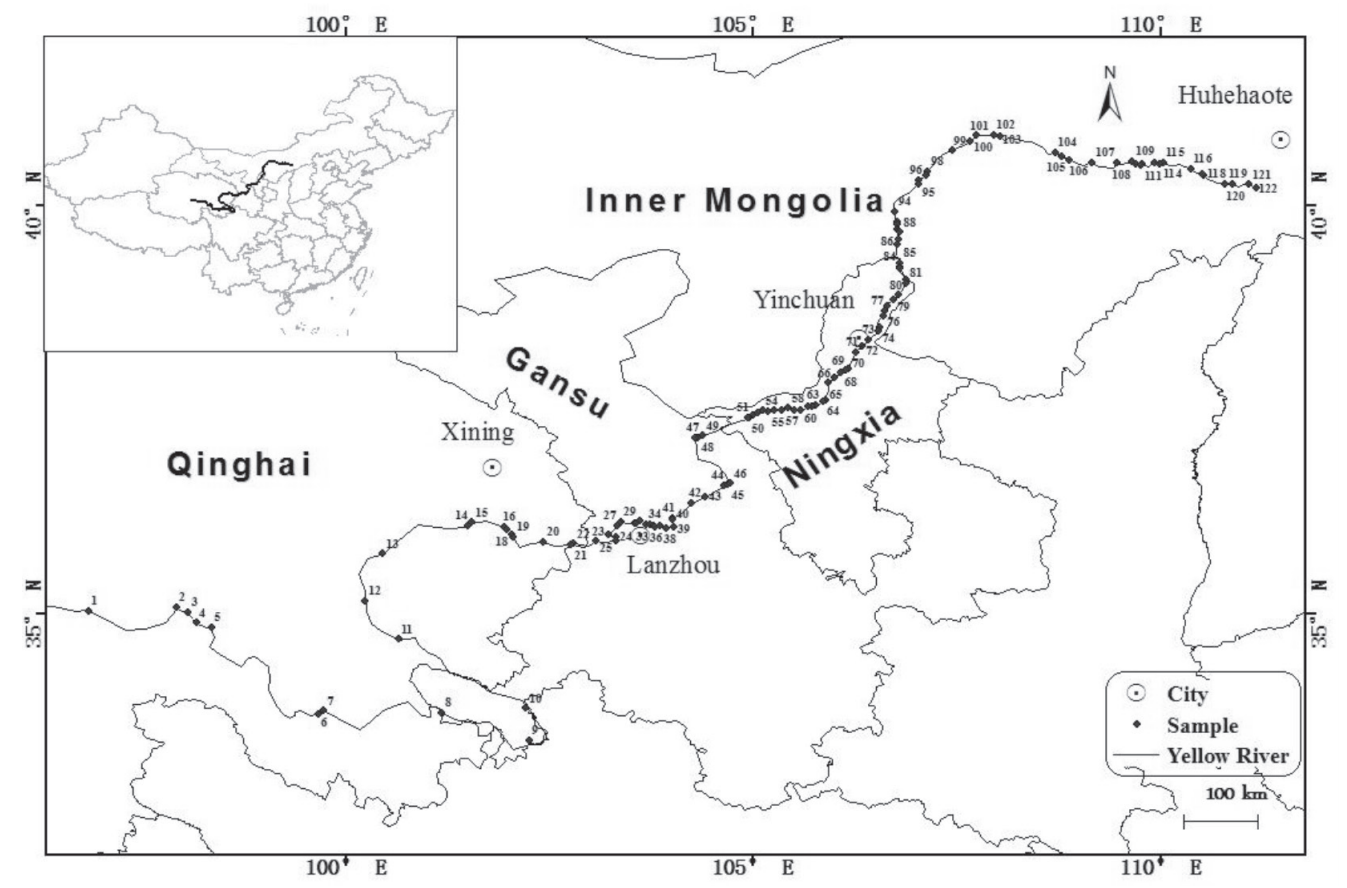

Fig. 1. Map of the study area and locality of sampling sites. 
of hydroelectric generation, flood control and water supply a series of dams are built which have altered the quantity and quality of river sediment.

\section{Sample Collection}

122 surface sediment samples $(0-5 \mathrm{~cm})$ were collected along the upstream Yellow River using a grab sampler (Fig. 1). Locations of all sampling sites were determined by a global positioning system and their surrounding environments were written down in the notebook. These samples were sealed in clean polyethylene bags and transported to the soil laboratory of Lanzhou Jiaotong University. These samples need to be air-dried, ground, digested and frozen specifically before determination.

\section{Chemical Analyses}

After air dried, all samples passed a $2 \mathrm{~mm}$ nylon sieve to remove the organic debris and a $0.063 \mathrm{~mm}$ mesh sieves through grinding. At last they were frozen for further analysis [32]. For the determination of heavy metal concentrations, $0.5 \mathrm{~g}$ sediment sample was accurately weighed, completely digested by successively adding concentrated $\mathrm{HCL}-\mathrm{HNO}_{3}-\mathrm{HClO}_{4}$ $\mathrm{HF}$ and heated at $180^{\circ} \mathrm{C}$ in a Teflon container. When the liquid containing sediment sample turned into a small golden droplet, it was diluted with $100 \mathrm{ml}$ deionized water, filtered with a membrane and measured the concentrations of heavy metals with inductively coupled plasma mass spectrometer (ICP-MS).

In this study, glassware was washed used de-ionized water after soaking them in $15 \% \mathrm{HNO}_{3}$ for the further experimentation. The treatment of every sample was triplicate and the analytical datum were average values of the triplicates in this study.

\section{Multivariate Statistical Analyses}

Principle component analysis (PCA) can transform the original heavy metal variables into several principal components $\left(\mathrm{PC}_{\mathrm{s}}\right)$ which reveal the similarity between heavy metals and confirm the potential pollution sources of heavy metals in sediments of aquatic systems [33-34]. Kaiser-Meyer-Olkin (KMO) and Bartlett's sphericity tests were conducted to verdict whether the data can be used for PCA.

Hierarchical cluster analysis (HCA), a useful data classification technique, was conducted to sort all heavy metals on the basis of their similarities [6, 35]. The similarity degrees about metals were measured by using Ward's method and squared Euclidean distances. The results of similarity can be shown in a visual dendrogram. Correlation analysis (CA) was also implemented to determine the relationship among metals and further verify the results obtained by multivariate analysis. Analyses were conducted using SPSS software 22.0 for Windows.

\section{Estimation of Sediment Contamination}

Numerous sediment quality guidelines (SQGs) are widely used to evaluate contaminant toxicity or risks to aquatic ecosystems by comparing sediment contaminant concentration with the corresponding quality guidelines $[9,36]$. Consensus-based SQGs which were determined by calculating the geometric mean of the published SQGs are likely to be directly relevant for assessing freshwater sediments that are influenced by multiple sources of contaminants [37]. These synthesized guidelines included a threshold effect concentration (TEC) and a probable effect concentration (PEC). TECs were interpreted to represent chemical concentrations below which adverse effects rarely occur. In contrast to TECs, PECs were intended to represent chemical concentrations above which adverse effects were likely to be frequently observed.

Mean PEC quotient (M-PEC-Q) was also useful ecological risk assessment to recognize and prioritize regions of potential hazards with respect to quality of sediments [36-38]. M-PEC-Q was calculated using the following equation [37-39]:

$$
\mathrm{M}-\mathrm{PEC}-\mathrm{Q}=\frac{\sum_{i=1}^{n} \frac{C_{i}}{P E C_{i}}}{n}
$$

...where $C_{i}$ was the concentration of metal in sediments, $P E C_{i}$ was the corresponding guideline values for the element $i$ and $\mathrm{n}$ was the number of metals. In the evaluation, sediment samples were predicted to be not toxic if M-PEC-Qs were less than 0.5. In contrast, sediment samples were predicted to be toxic when M-PEC-Qs exceeded 1.5.

Enrichment factor (EF) was widely used as an appropriate approach to determine the pollution degree in sediments of aquatic ecosystems. To identify anomalous metal concentrations, a normalization metal was employed. In this study, Mn element was used as reference material $[20,40]$. EF was calculated as:

$$
\mathrm{EF}=\frac{\left(\frac{\mathrm{M}}{\mathrm{Mn}}\right)_{\text {sample }}}{\left(\frac{\mathrm{M}}{\mathrm{Mn}}\right)_{\text {backgroud }}}
$$

...where $\left(\frac{\mathrm{M}}{\mathrm{Mn}}\right)$ sample was the ratio of metal (M) and Mn concentrations of the sample, and $\left(\frac{\mathrm{M}}{\mathrm{Mn}}\right)$ backgroud was the ratio of metal $(\mathrm{M})$ and $\mathrm{Mn}$ concentrations of the background. The background concentrations of $\mathrm{Fe}, \mathrm{Cu}$, $\mathrm{Ni}, \mathrm{Zn}, \mathrm{Cr}, \mathrm{Pb}$, and $\mathrm{Cd}$ were 47200, 45, 68, 95, 90, 20, and $0.3 \mathrm{mg} / \mathrm{kg}$, respectively [41]. The EF levels were interpreted as reported in Table 1.

Müller (1969) proposed the geoaccumulation index $\left(\mathrm{I}_{\text {geo }}\right)$ to evaluate the heavy metal contamination in sediments, which was applied using the following equation: 
Table 1. Classification standard of enrichment factor $(\mathrm{EF})$ and geoaccumulation index $\left(\mathrm{I}_{\mathrm{geo}}\right)$.

\begin{tabular}{|c|c|c|c|c|}
\hline EF classes & Enrichment level & $\mathrm{I}_{\text {geo }}$ value & $\mathrm{I}_{\text {geo }}$ Class & Contamination level \\
\hline $\mathrm{EF}<1$ & No enrichment & $\mathrm{I}_{\text {geo }} \leq 0$ & 0 & Uncontaminated \\
\hline $\mathrm{EF}=1-3$ & Minor enrichment & $\mathrm{I}_{\text {geo }}=0-1$ & 1 & Uncontaminated/moderately contaminated \\
\hline $\mathrm{EF}=3-5$ & Moderate enrichment & $\mathrm{I}_{\mathrm{geo}}=1-2$ & 2 & Moderately contaminated \\
\hline $\mathrm{EF}=5-10$ & Moderately severe enrichment & $\mathrm{I}_{\mathrm{geo}}=2-3$ & 3 & Moderately/strongly contaminated \\
\hline $\mathrm{EF}=10-25$ & Severe enrichment & $\mathrm{I}_{\mathrm{geo}}=3-4$ & 4 & Strongly contaminated \\
\hline $\mathrm{EF}=25-50$ & Very severe enrichment & $\mathrm{I}_{\text {geo }}=4-5$ & 5 & Strongly /extremely contaminated \\
\hline $\mathrm{EF}>50$ & Extremely severe enrichment & $\mathrm{I}_{\mathrm{geo}}>5$ & 6 & Extremely contaminated \\
\hline
\end{tabular}

$$
\mathrm{I}_{\mathrm{geo}}=\log _{2}\left(\frac{\mathrm{C}_{\mathrm{n}}}{1.5 \mathrm{~B}_{\mathrm{n}}}\right)
$$

...where $\mathrm{C}_{\mathrm{n}}$ was the measured concentration of trace metal in sediment, $\mathrm{B}_{\mathrm{n}}$ was the geochemical background value of the corresponding metal [41]. The factor of 1.5 was used to minimize the effects of possible variations in the background values due to lithogenic effects. A seven-level classification of $\mathrm{I}_{\text {geo }}$ was defined in Table 1.

The potential ecological risk index (RI) introduced by Hakanson (1980) was used to assess the degree of heavy metal pollution in sediment according to the toxicity of heavy metal and the response of the environment [42]. RI was calculated using the following formulas:

$$
\mathrm{RI}=\sum_{i}^{m} E_{r}^{i}=\sum_{i}^{m} T_{r}^{i} C_{f}^{i}=\sum_{i}^{m} T_{r}^{i} C_{n}^{i} / C_{r}^{i}
$$

...where RI was the sum of all risk factors for heavy metals in sediment, $E_{r}^{i}$ was the monomial potential ecological risk factor of each heavy metal, $T_{r}^{i}$ was the toxic-response factor for heavy metal $i$. According to Hakanson (1980), $T_{r}$ for $\mathrm{Cu}, \mathrm{Ni}, \mathrm{Zn}, \mathrm{Cr}, \mathrm{Pb}, \mathrm{Cd}$ are 5, 5, $1,2,5$, and 30 respectively. $C_{f}^{i}$ was the contamination factor of heavy metal $i, C_{n}{ }^{i}$ was the measured concentration of heavy metal $i, C_{r}{ }^{i}$ was the background of heavy metal $i$. Standards of ecological risk levels were shown in Table 2 [42-43].

\section{Results and Discussion}

\section{Evaluation of Heavy Metal Pollution}

To estimate the degree of metals contamination in the surface sediments of the upstream Yellow River, $\mathrm{EF}$ and the $\mathrm{I}_{\text {geo }}$ for each element were calculated. The median $\mathrm{EF}$ values for $\mathrm{Fe}, \mathrm{Mn}, \mathrm{Cu}, \mathrm{Ni}$ and $\mathrm{Pb}$ were $<1$, indicating no enrichment of these metals in the sediment. The median $\mathrm{EF}$ values for $\mathrm{Zn}$ and $\mathrm{Cr}$ showed minor enrichment while $\mathrm{Cd}$ indicated moderately severe enrichment due to anthropogenic inputs (Fig. 2a). The median $I_{\text {geo }}$ values except for $\mathrm{Cd}$ were less than 1, placing these metals into the uncontaminated, while the $\mathrm{I}_{\text {geo }}$ value of Cd was mostly higher than 1 in upstream Yellow River for moderately contaminated level (Fig. 2b). The median of $\mathrm{I}_{\text {geo }}$ values for these metals decreased in the order of $\mathrm{Cd}>\mathrm{Cr}>\mathrm{Zn}>\mathrm{Mn} / \mathrm{Fe} / \mathrm{Ni}>\mathrm{Cu} /$ $\mathrm{Pb}$, which is similar with that observed from $\mathrm{EF}$ values. Overall, the mean EF was 1.47 and ranged from no enrichment to minor enrichment level, and the mean $\mathrm{I}_{\text {geo }}$ was -0.88 and belonged to uncontaminated level in the upstream Yellow River (Fig. 3).

To evaluate the toxicity and potential risk of heavy metals in sediments of the upstream Yellow River, SQGs and RI were applied. A comparison of the metals concentrations with the TEC and PEC values showed that $0 \%$ of the samples exceeded the PEC for all metals except $\mathrm{Ni}$ and $\mathrm{Cr}$. The concentrations of $\mathrm{Ni}$ and $\mathrm{Cr}$ in $25.4 \%$ and $36.9 \%$ sediment samples were higher than their corresponding PEC, respectively, implying potential harm for aquatic organisms. Approximately

Table 2. Standards of potential ecological risk index of $E_{r}{ }^{i}$ and RI suggested by Hakanson (1980).

\begin{tabular}{|c|c|c|c|}
\hline$E_{r}{ }^{i}$ & Level & $\mathrm{RI}$ & Level \\
\hline$E_{r}{ }^{i}<40$ & Low risk & $\mathrm{RI}<95$ & Low risk \\
\hline $40 \leq E_{r}{ }^{i}<80$ & Moderate risk & $95 \leq \mathrm{RI}<190$ & Moderate risk \\
\hline $80 \leq E_{r}{ }^{i}<160$ & Considerable risk & $190 \leq \mathrm{RI}<380$ & Very high risk \\
\hline $160 \leq E_{r}{ }^{i}<320$ & High risk & $\mathrm{RI} \geq 380$ & \\
\hline$E_{r}{ }^{i} \geq 320$ & Very high risk & & \\
\hline
\end{tabular}



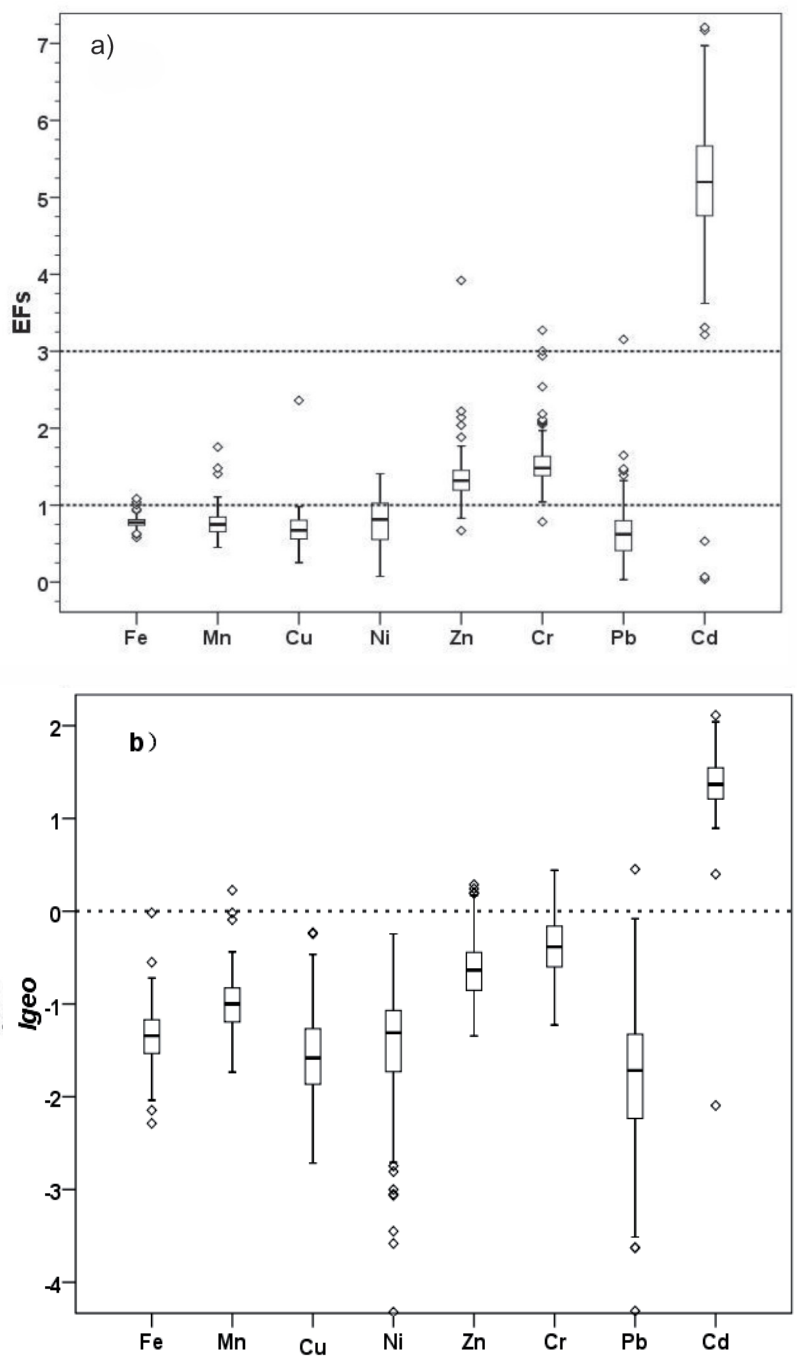

Fig. 2. Boxplots of a) enrichment factors (EF) and b) geoaccumulation indexes $\left(I_{\text {geo }}\right)$ of heavy metals in the surface sediments of the upstream Yellow river.

84.4\% for Cd was between the TEC and PEC, also suggesting potential adverse effects. In contrast, $89.3 \%$ for $\mathrm{Cu}, 87.7 \%$ for $\mathrm{Zn}$ and $99.2 \%$ for $\mathrm{Pb}$ were below
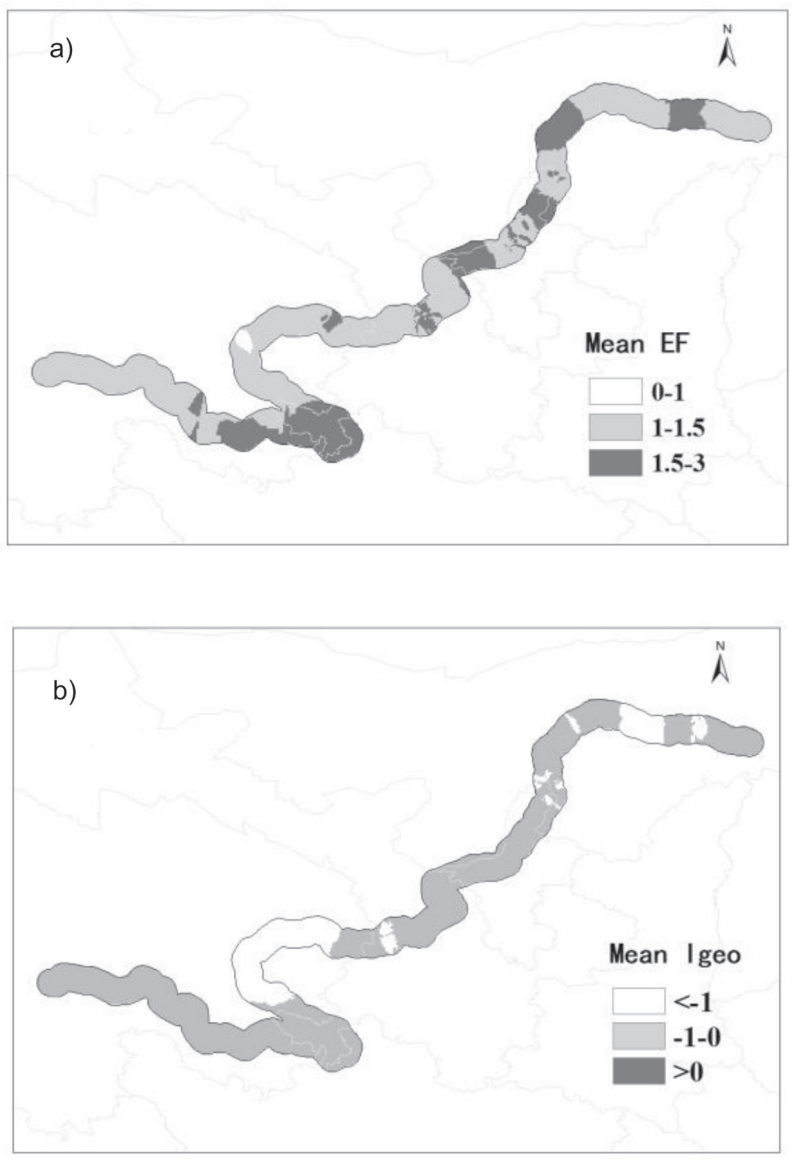

Fig. 3. The spatial distribution of a) enrichment factors (EF) and b) geoaccumulation indexes ( $\left.\mathrm{I}_{\mathrm{geo}}\right)$ of heavy metals in the surface sediments of the upstream Yellow river.

their TEC, indicating a low probability of adverse effects (Table 3). To further evaluate their toxic risk, the PEC quotients (PEC-Q) were calculated according to the definition reported by MacDonald. (2000) [37]. The mean PEC-Q varied from 0.08 to $0.96 \mathrm{mg} / \mathrm{kg}$ (with a mean value of $0.41 \mathrm{mg} / \mathrm{kg}$ ), indicating integrally no toxic in the upstream Yellow River (Table 3, Fig. 4a). The maximal PEC-Qs for all metals except for Ni

Table 3. Percentages of sediments samples above PEC, between TEC and PEC, and below TEC, and summary description of PEC quotients for heavy metals in the upstream of Yellow River.

\begin{tabular}{|c|c|c|c|c|c|c|}
\hline SQGs & $\mathrm{Cu}$ & $\mathrm{Ni}$ & $\mathrm{Zn}$ & $\mathrm{Cr}$ & $\mathrm{Pb}$ & $\mathrm{Cd}$ \\
\hline TEC & 31.6 & 22.7 & 121 & 43.40 & 35.8 & 0.99 \\
\hline PEC & 149 & 48.6 & 459 & 111.00 & 128 & 4.98 \\
\hline >PEC (\%) & 0 & 25.4 & 0 & 36.9 & 0 & 0 \\
\hline Between TEC and PEC (\%) & 10.3 & 58.2 & 12.3 & 63.1 & 0.8 & 84.4 \\
\hline <TEC (\%) & 89.3 & 16.4 & 87.7 & 0 & 99.2 & 15.6 \\
\hline Mean PEC-Q & 0.16 & 0.81 & 0.21 & 0.96 & 0.08 & 0.24 \\
\hline Minimal PEC-Q & 0.07 & 0.11 & 0.12 & 0.52 & 0.004 & 0.002 \\
\hline Maximal PEC-Q & 0.39 & 1.77 & 0.38 & 1.65 & 0.32 & 0.39 \\
\hline
\end{tabular}



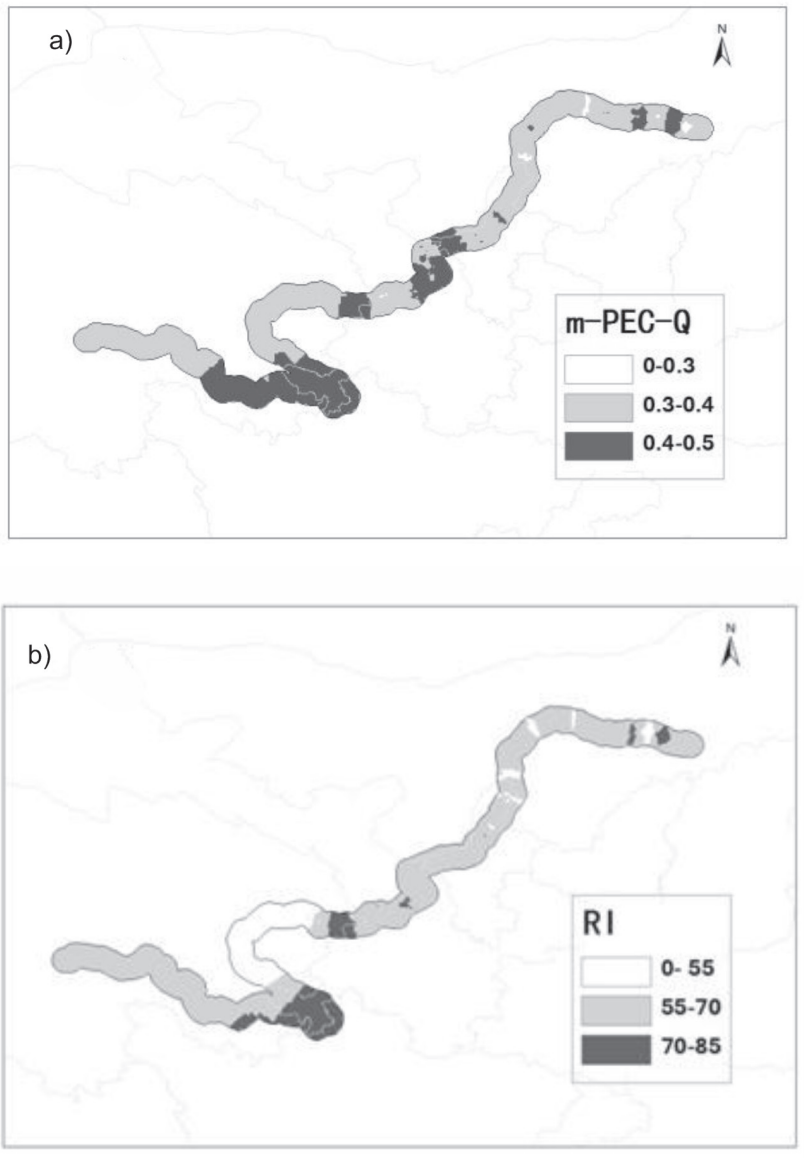

Fig. 4. Spatial distribution of mean PEC quotient a) and potential ecological risk index b) for the upstream Yellow river.

and $\mathrm{Cr}$ were below $0.5 \mathrm{mg} / \mathrm{kg}$, indicating that all samples of $\mathrm{Cu}, \mathrm{Zn}, \mathrm{Pb}$ and $\mathrm{Cd}$ were no toxic to sediment-dwelling organisms. The Ni PEC-Q of site 16 and site 49 and the Cr PEC-Q of site 17 and site 42 were higher than $1.5 \mathrm{mg} / \mathrm{kg}$, suggesting these sample sites were likely to result in potential harmful effects on sediment dwelling organisms, which was similar to spatial distribution of mean PEC quotient (Fig. 4a).

The RI can be used to quantitatively evaluate the potential risk of one metal or a combination of multiple metals. Among the six heavy metals, $\mathrm{E}_{\mathrm{r}}$ values for $\mathrm{Cd}$ were biggest and varied largely through the study area (0.31 to 59.57), with a mean value of 35.34 . $\mathrm{E}_{\mathrm{r}}$ values for $25 \%$ of $\mathrm{Cd}$ sites were larger than 40 , suggesting considerable potential ecological risk, whereas $\mathrm{E}_{\mathrm{r}}$ values for the other five heavy metals were below 15 (Table 4). In the surface sediments from the upstream of Yellow River, the calculated values of RI for six studied heavy metals in 122 sites varied from 19.43 to 95.15 , with a mean value of 61.97 . RI value of only one site (site 31) in 122 sites excessed 95, suggesting a low potential ecological risk in general (Table 4; Fig. 4b). Overall, the evaluated results and spatial distribution of m-PEC-Q and RI were similar (Table 3, 4; Fig. 4).

\section{Identification of Heavy Metal Sources}

It is important to analyze the sources of heavy metals pollution because heavy metals in sediments have been showed to threat the health of aquatic animals and humans. Multivariate analysis (pearson correlation, cluster and principal component analysis) has been proved to be an effective tool for providing suggestive information regarding heavy metal sources and pathways.

$\mathrm{CA}$ analyses showed that both $\mathrm{Fe}$ and $\mathrm{Mn}$ concentrations were positively correlated with that of $\mathrm{Cu}, \mathrm{Zn}, \mathrm{Cr}$ and $\mathrm{Cd}$, but not with $\mathrm{Ni}$ and $\mathrm{Pb}$ (Table 5). This indicated that $\mathrm{Cu}, \mathrm{Zn}, \mathrm{Cr}$ and $\mathrm{Cd}$ may mostly originated from the similar sources with $\mathrm{Fe}$ and $\mathrm{Mn}$, such as natural source of lithogenic materials. Moreover, $\mathrm{Cd}$ and $\mathrm{Cu}$ also were positively correlated with $\mathrm{Ni}$, which suggested that the concentrations of $\mathrm{Cd}$ and $\mathrm{Cu}$ were also influenced by mining and smelting activities apart from its natural sources. The pollution source of $\mathrm{Ni}$ was related to the anthropogenic outputs of $\mathrm{Cd}$ and $\mathrm{Cu}$.

PCA was applied to determine the pollution degrees of heavy metals from lithogenic action and anthropogenic sources [44]. The calculated value of KMO was 0.74 and the significance level of Bartlett's Sphericity was 0 (less than 0.05), indicating compatibility of data for PCA can be useful in dimensionality reductions. Three main components with eigenvalues higher than 1 were determined, explaining $72.44 \%$ of the total variance, which indicated that the original dataset can be represented by three new variables of PCs (Table 6 and Fig. 5). On PC1 (40.95\% of the total variance), $\mathrm{Fe}, \mathrm{Mn}, \mathrm{Zn}, \mathrm{Cr}$ and $\mathrm{Cd}$ have strong positive loading, and moderate positive loading

Table 4. Basic statistical summary of potential ecological risk index.

\begin{tabular}{|c|c|c|c|c|c|c|c|}
\hline \multirow{2}{*}{} & \multicolumn{7}{|c|}{ Er } \\
\cline { 2 - 8 } & $\mathrm{Cu}$ & $\mathrm{Ni}$ & $\mathrm{Zn}$ & $\mathrm{Cr}$ & $\mathrm{Pb}$ & $\mathrm{Cd}$ & RI \\
\hline Mean & 4.75 & 10.05 & 1.38 & 6.44 & 2.41 & 35.34 & 61.67 \\
\hline Minimum & 2.06 & 1.28 & 0.79 & 3.30 & 0.13 & 0.31 & 19.43 \\
\hline Maximum & 11.50 & 21.53 & 2.45 & 10.48 & 10.26 & 59.57 & 95.15 \\
\hline Class & Low risk & Low risk & Low risk & Low risk & Low risk & Low risk & Low risk \\
\hline
\end{tabular}


Table 5. Correlation coefficients between different heavy metal elements $(n=122)$.

\begin{tabular}{|l|l|l|l|l|l|l|l|l|}
\hline & $\mathrm{Fe}$ & $\mathrm{Mn}$ & $\mathrm{Cu}$ & $\mathrm{Ni}$ & $\mathrm{Zn}$ & $\mathrm{Cr}$ & $\mathrm{Pb}$ & $\mathrm{Cd}$ \\
\hline $\mathrm{Fe}$ & 1 & & & & & & \\
\hline $\mathrm{Mn}$ & $0.907^{* *}$ & 1 & & & & & & \\
\hline $\mathrm{Cu}$ & $0.40^{* *}$ & $0.493^{* *}$ & 1 & & & & & \\
\hline $\mathrm{Ni}$ & 0.045 & 0.066 & $0.266^{* *}$ & 1 & & & & \\
\hline $\mathrm{Zn}$ & $0.497^{* *}$ & $0.561^{* *}$ & $0.180^{* *}$ & $0.232^{*}$ & 1 & & & \\
\hline $\mathrm{Cr}$ & $0.521^{* *}$ & $0.559^{* *}$ & $0.253^{* *}$ & 0.114 & $0.523^{* *}$ & 1 & & \\
\hline $\mathrm{Pb}$ & 0.113 & 0.128 & 0.174 & 0.047 & $0.201^{*}$ & $0.217^{*}$ & 1 & \\
\hline $\mathrm{Cd}$ & $0.529^{* *}$ & $0.493^{* *}$ & $0.465^{* *}$ & $0.330^{* *}$ & $0.360^{* *}$ & $0.515^{* *}$ & 0.136 & 1 \\
\hline
\end{tabular}

Levels of significance: ${ }^{*} \mathrm{P}<0.05$; $* * \mathrm{P}<0.01$.

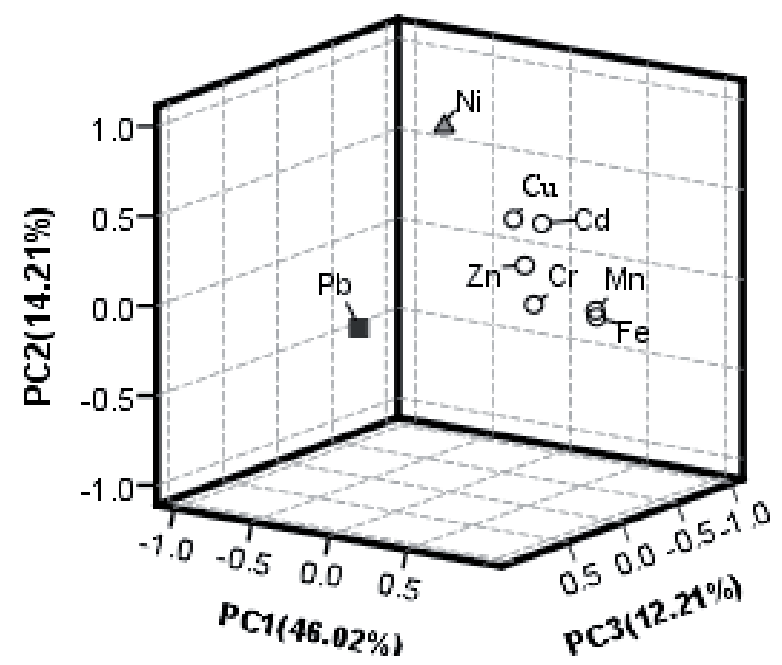

Fig. 5. Principal component loading plot for metal variables.

Table 6. Total variance explained and rotated component matrix of principal components analysis.

\begin{tabular}{|c|c|c|c|}
\hline & PC1 & PC2 & PC3 \\
\hline $\mathrm{Fe}$ & $\mathbf{0 . 9 2}$ & -0.004 & -0.04 \\
\hline $\mathrm{Mn}$ & $\mathbf{0 . 9 4}$ & 0.04 & -0.01 \\
\hline $\mathrm{Cu}$ & $\mathbf{0 . 5 1}$ & $\mathbf{0 . 5 0}$ & 0.12 \\
\hline $\mathrm{Ni}$ & -0.04 & $\mathbf{0 . 9 2}$ & -0.002 \\
\hline $\mathrm{Zn}$ & $\mathbf{0 . 6 5}$ & 0.30 & 0.23 \\
\hline $\mathrm{Cr}$ & $\mathbf{0 . 7 1}$ & 0.09 & 0.24 \\
\hline $\mathrm{Pb}$ & 0.09 & 0.03 & $\mathbf{0 . 9 7}$ \\
\hline $\mathrm{Cd}$ & $\mathbf{0 . 6 1}$ & $\mathbf{0 . 4 9}$ & 0.03 \\
\hline Eigenvalue & 3.28 & 1.45 & 1.07 \\
\hline \% Total variance & 40.95 & 18.09 & 13.40 \\
\hline \% Cumulative variance & 40.95 & 59.04 & 72.44 \\
\hline
\end{tabular}

Extraction method: principal component analysis. Rotation method: Varimax with Kaiser normalization. for $\mathrm{Cu}$, suggesting these metals might come from the erosion of the parent rock and its weathering crusts and they might be mainly control sources of pollution. PC2 (18.09\% of the total variance) has strong positive loading on $\mathrm{Ni}$, moderate positive loading for $\mathrm{Cu}$ and $\mathrm{Cd}$, weak positive loading for $\mathrm{Mn}$ and negative positive loading for Fe. The results showed $\mathrm{Ni}, \mathrm{Cu}$ and $\mathrm{Cd}$ likely originate from similar anthropogenic pollution sources. However, $\mathrm{Cu}$ and $\mathrm{Cd}$ also show moderate to strong positive loading on $\mathrm{PC} 1$, suggesting that the sources of $\mathrm{Cu}$ and $\mathrm{Cd}$ could be both natural and anthropogenic. PC3 (13.4\% of the total variance) demonstrates strong positive loading for $\mathrm{Pb}$ and negative positive loading for $\mathrm{Fe}, \mathrm{Mn}$ and $\mathrm{Ni}$, suggesting $\mathrm{Pb}$ has another different anthropogenic source.

To confirm the association obtained from CA and PCA, HCA was preformed to find out the relationship between heavy metals. The dendrogram with single linkage Euclidean distance was showed in Fig. 6. The

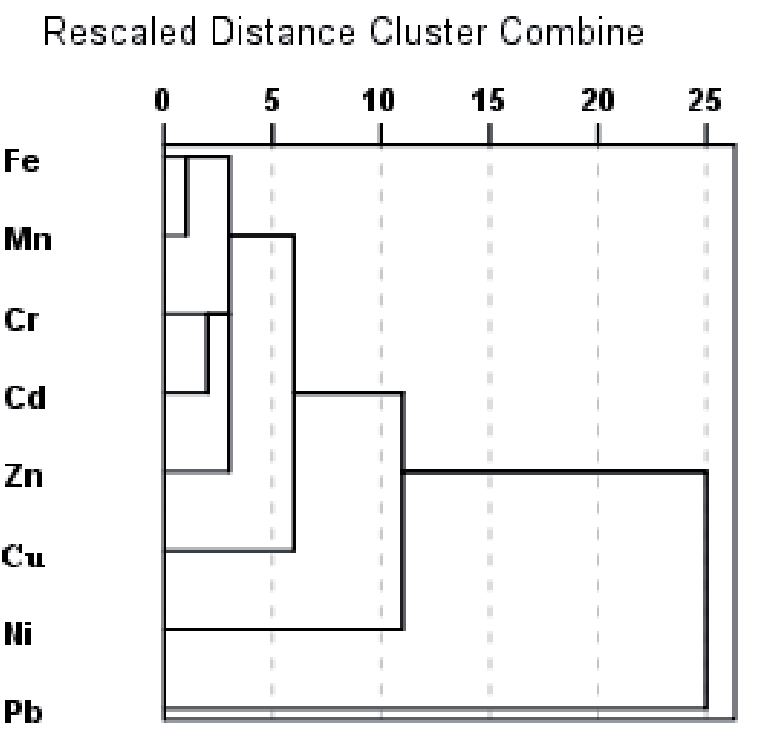

Fig. 6. Dendrogram of cluster analysis for parameters in the sediments of study area. 
distance axis represented the degrees of association between groups of variables, the lower the value on the axis, the more significant the association. In this dendrogram, all 8 parameters were grouped into three statistically meaningful clusters. Cluster 1 contained $\mathrm{Fe}, \mathrm{Mn}, \mathrm{Cu}, \mathrm{Zn}, \mathrm{Cr}$ and $\mathrm{Cd}$ which could mostly be originated from natural sources. Cluster 2 and Cluster 3 contained $\mathrm{Ni}$ and $\mathrm{Pb}$, respectively. $\mathrm{Ni}$ and $\mathrm{Pb}$ derived from different anthropogenic sources. Overall, the results of CA, PCA and HCA were consistent.

\section{Conclusions}

Pollution evaluation and sources identification of heavy metals ( $\mathrm{Fe}, \mathrm{Mn}, \mathrm{Cu}, \mathrm{Ni}, \mathrm{Zn}, \mathrm{Cr}, \mathrm{Pb}$ and $\mathrm{Cd}$ ) were analyzed in surface sediments from upstream of Yellow River. Based on the background values presented by Turekian in 1961, all of the heavy metals had different accumulated levels for the order: $\mathrm{Cd}>\mathrm{Cr}>\mathrm{Zn}>\mathrm{Mn} / \mathrm{Fe} / \mathrm{Ni}>\mathrm{Cu} / \mathrm{Pb}$, which was similar to that by Reference [30]. Among these metals, Cd enrichment was significant, while the upstream Yellow River was basically uncontaminated, which was attested by the values of EF and $\mathrm{I}_{\mathrm{geo}}$. According to TEC-PEC SQGs and $\mathrm{RI}$, only $\mathrm{Ni}$ and $\mathrm{Cr}$ in part of the sites had potentially harmful effects and the other metals had no toxic in the upstream Yellow River. In light of multivariate analyses (CA, PCA and HCA), Fe, $\mathrm{Mn}, \mathrm{Zn} \mathrm{Cr}, \mathrm{Cu}$ and $\mathrm{Cd}$ were mostly originated from natural sources, while $\mathrm{Ni}$ and $\mathrm{Pb}$ mainly derived from different anthropogenic sources and a small number of $\mathrm{Cu}$ and $\mathrm{Cd}$ come from anthropogenic sources of $\mathrm{Ni}$ discharge. Therefore, it is necessary for the government to control quality of sewage discharge containing $\mathrm{Ni}$.

\section{Acknowledgements}

This work was supported by the National Natural Science Foundation of China (51668034, 31560161) and Program for Changjiang Scholars and Innovative Research Team in University (IRT0966).

\section{Conflict of Interest}

The authors declare no conflict of interest.

\section{References}

1. YUAN H., SONG J., LI X., LI N., DUAN L. Distribution and contamination of heavy metals in surface sediments of the South Yellow Sea. Mar Pollut Bull, 64 (10), 2151, 2012.

2. HUANG L., PU X., PAN J.F., WANG B. Heavy metal pollution status in surface sediments of Swan Lake lagoon and Rongcheng Bay in the northern Yellow Sea. Chemosphere, 93 (9), 1957, 2013.
3. GUAN Q., WANG L., PAN B., GUAN W., SUN X., CAI A. Distribution features and controls of heavy metals in surface sediments from the riverbed of the Ningxia-Inner Mongolian reaches, Yellow River, China. Chemosphere, 144, 29, 2016.

4. DAVUTLUOGLU O.I., SECKIN G., ERSU C.B., YILMAZ T., SARI B. Heavy metal content and distribution in surface sediments of the Seyhan River, Turkey. J Environ Manage, 92 (9), 2250, 2011.

5. ZHANG W., LIU X., CHENG H., ZENG E.Y., HU Y. Heavy metal pollution in sediments of a typical mariculture zone in South China. Mar Pollut Bull, 64 (4), 712, 2012.

6. PEJMAN A., NABI BIDHENDI G., ARDESTANI M., SAEEDI M., BAGHVAND A. A new index for assessing heavy metals contamination in sediments: A case study. Ecological Indicators, 58, 365, 2015.

7. LIU M., ZHANG A., LIAO Y., CHEN B., FAN D. The environment quality of heavy metals in sediments from the central Bohai Sea. Mar Pollut Bull, 100 (1), 534, 2015.

8. CHEN C.W., KAO C.M., CHEN C.F., DONG C.D. Distribution and accumulation of heavy metals in the sediments of Kaohsiung Harbor, Taiwan. Chemosphere, 66 (8), 1431, 2007.

9. VAROL M. Assessment of heavy metal contamination in sediments of the Tigris River (Turkey) using pollution indices and multivariate statistical techniques. J Hazard Mater, 195, 355, 2011.

10. WANG C., LIU S., ZHAO Q., DENG L., DONG S. Spatial variation and contamination assessment of heavy metals in sediments in the Manwan Reservoir, Lancang River. Ecotoxicol Environ Saf, 82, 32, 2012.

11. YANG J., CHEN L., LIU L.Z., SHI W.L., MENG X.Z. Comprehensive risk assessment of heavy metals in lake sediment from public parks in Shanghai. Ecotoxicol Environ Saf, 102, 129, 2014.

12. SURESH G., RAMASAMY V., SUNDARRAJAN M., PARAMASIVAM K. Spatial and vertical distributions of heavy metals and their potential toxicity levels in various beach sediments from high-background-radiation area, Kerala, India. Mar Pollut Bull, 91 (1), 389, 2015.

13. HU Y., CHENG H. Application of stochastic models in identification and apportionment of heavy metal pollution sources in the surface soils of a large-scale region. Environ Sci Technol, 47 (8), 3752, 2013.

14. CHEN H., TENG Y., LI, J., WU J., WANG J. Source apportionment of trace metals in river sediments: A comparison of three methods. Environ Pollut, 211, 28, 2016.

15. PEKEY H., KARAKAS D., AYBERK S., TOLUN L., BAKOGLU M. Ecological risk assessment using trace elements from surface sediments of Izmit Bay (Northeastern Marmara Sea) Turkey. Mar Pollut Bull, 48 (9-10), 946, 2004.

16. BAI J., CUI B., CHEN B., ZHANG K., DENG W., GAO H., XIAO R. Spatial distribution and ecological risk assessment of heavy metals in surface sediments from a typical plateau lake wetland, China. Ecological Modelling, 222 (2), 301, 2011.

17. BASTAMI K.D., BAGHERI H., HAGHPARAST S., SOLTANI F., HAMZEHPOOR A., BASTAMI M.D. Geochemical and geo-statistical assessment of selected heavy metals in the surface sediments of the Gorgan Bay, Iran. Mar Pollut Bull, 64 (12), 2877, 2012.

18. ZHAO S., FENG C., WANG D., TIAN C., SHEN Z. Relationship of metal enrichment with adverse biological 
effect in the Yangtze Estuary sediments: role of metal background values. Environ Sci Pollut Res Int, 21 (1), 464, 2014.

19. ZHANG Z., JUYING L., MAMAT Z., QINGFU Y. Sources identification and pollution evaluation of heavy metals in the surface sediments of Bortala River, Northwest China. Ecotoxicol Environ Saf, 126, 94, 2016.

20. ZAHRA A., HASHMI M.Z., MALIK R.N., AHMED Z. Enrichment and geo-accumulation of heavy metals and risk assessment of sediments of the Kurang Nallah-feeding tributary of the Rawal Lake Reservoir, Pakistan. Sci Total Environ, 470, 925, 2014.

21. ZHANG Z., JILILI A., JIANG F. Heavy metal contamination, sources, and pollution assessment of surface water in the Tianshan Mountains of China. Environ Monit Assess, 187 (2), 33, 2015.

22. YAN N., LIU W., XIE H., GAO L., HAN Y., WANG M., LI, H. Distribution and assessment of heavy metals in the surface sediment of Yellow River, China. J Environ Sci (China), 39( 45), 2016.

23. FAN Q., HE J., XUE H., LÜ C., SUN Y., SHEN L., LIANG Y., BAI S. Heavy metal pollution in the Baotou section of the Yellow River, China. Chemical Speciation \& Bioavailability, 20 (2), 65, 2015.

24. RAO Q., SUN Z., TIAN L., LI J., SUN W., SUN W. Assessment of arsenic and heavy metal pollution and ecological risk in inshore sediments of the Yellow River estuary, China. Stochastic Environmental Research and Risk Assessment, 32 (10), 2889, 2018.

25. LI P., QIAN H., HOWARD K.W.F., WU J. Heavy metal contamination of Yellow River alluvial sediments, northwest China. Environmental Earth Sciences, 73 (7), 3403, 2014.

26. CHEN,Y., JIANG Y., HUANG H., MOU L., RU J., ZHAO J., XIAO S. Long-term and high-concentration heavymetal contamination strongly influences the microbiome and functional genes in Yellow River sediments. Sci Total Environ, 637-638, 1400, 2018.

27. CHENG Q., WANG W., WANG H., ZHAO Z. Investigation of the Heavy Metal Contamination of the Sediments from the Yellow River Wetland Nature Reserve of Zhengzhou, China. Iranian J Publ Health, 41 (3), 26, 2012.

28. CHENG Q., ZHOU W., ZHANG J., SHI L., XIE Y., LI X. Spatial variations of arsenic and heavy metal pollutants before and after the water-sediment regulation in the wetland sediments of the Yellow River Estuary, China. Mar Pollut Bull, 145, 138, 2019.

29. HU B., LI J., BI N., WANG H., YANG J., WEI H., ZHAO J., LI G., YIN X., LIU M., ZOU L., LI S. Seasonal variability and flux of particulate trace elements from the Yellow River: impacts of the anthropogenic flood event. Mar Pollut Bull, 91 (1), 35, 2015.

30. MA X., ZUO H., TIAN M., ZHANG L., MENG J., ZHOU X., MIN N., CHANG X., LIU Y. Assessment of heavy metals contamination in sediments from three adjacent regions of the Yellow River using metal chemical fractions and multivariate analysis techniques. Chemosphere, 144, 264, 2016.
31. WANG S., FU B., LIANG W., LIU Y., WANG Y. Driving forces of changes in the water and sediment relationship in the Yellow River. Sci Total Environ, 576, 453, 2017.

32. SAKAN S., GRZETIC I., DORDEVIC D. Distribution and fractionation of heavy metals in the Tisa (Tisza) river sediments. Environ Sci Pollut Res Int, 14 (4), 229, 2007.

33. OGWUELEKA T.C. Use of multivariate statistical techniques for the evaluation of temporal and spatial variations in water quality of the Kaduna River, Nigeria. Environ Monit Assess, 187 (3), 137, 2015.

34. JAHAN S., STREZOV V. Comparison of pollution indices for the assessment of heavy metals in the sediments of seaports of NSW, Australia. Mar Pollut Bull, 128, 295, 2018.

35. SURESH G., SUTHARSAN P., RAMASAMY V., VENKATACHALAPATHY R. Assessment of spatial distribution and potential ecological risk of the heavy metals in relation to granulometric contents of Veeranam lake sediments, India. Ecotoxicol Environ Saf, 84, 117, 2012.

36. ZHU L., LIU J., XU S., XIE Z. Deposition behavior, risk assessment and source identification of heavy metals in reservoir sediments of Northeast China. Ecotoxicol Environ Saf, 142, 454, 2017.

37. MACDONALD D.D., INGERSOLL C.G., BERGER T.A. Development and evaluation of consensus-based sediment quality guidelines for freshwater ecosystems. Arch Environ Contam Toxicol, 39 (1), 20, 2000.

38. VIOLINTZIS C., ARDITSOGLOU A., VOUTSA D. Elemental composition of suspended particulate matter and sediments in the coastal environment of Thermaikos Bay, Greece: delineating the impact of inland waters and wastewaters. J Hazard Mater, 166 (2-3), 1250, 2009.

39. LONG E.R., MACDONALD D.D. Recommended Uses of Empirically Derived, Sediment Quality Guidelines for Marine and Estuarine Ecosystems. Human and Ecological Risk Assessment: An International Journal, 4 (5), 1019, 1998.

40. SALATI S., MOORE F. Assessment of heavy metal concentration in the Khoshk River water and sediment, Shiraz, Southwest Iran. Environ Monit Assess, 164 (1-4), 677, 2010.

41. TUREKIAN K.K., WEDEPOHL K.H. Distribution of the elements in some major units of the earth's crust. Geol. Soc. Amer. Bull., 72 (2), 175, 1961.

42. HAKANSON L. An ecological risk index for aquatic pollution control. A sedimentological approach. Water Research, 14 (8), 975, 1980.

43. YI Y., YANG Z., ZHANG S. Ecological risk assessment of heavy metals in sediment and human health risk assessment of heavy metals in fishes in the middle and lower reaches of the Yangtze River basin. Environ Pollut, 159 (10), 2575, 2011.

44. SUN Y., ZHOU Q., XIE X., LIU R. Spatial, sources and risk assessment of heavy metal contamination of urban soils in typical regions of Shenyang, China. J Hazard Mater, 174 (1-3), 455, 2010. 
